\title{
Vloga svetovanja in svetovalcev na področju menedžmenta pri uvajanju organizacijskih sprememb
}

\author{
Idriz Selimović* \\ Fakulteta za organizacijske študije, Ulica talcev 3, 8000 Novo mesto, Slovenija \\ idrizselimovic@yahoo.com
}

Mirko Markič

Univerza na Primorskem, Fakulteta za management, Cankarjeva 5, 6000 Koper, Slovenija Fakulteta za organizacijske študije, Ulica talcev 3, 8000 Novo mesto, Slovenija mirko.markic@guest.arnes.si

\begin{abstract}
Povzetek:
Raziskovalno vprašanje (RV): Ali v organizaciji potrebujejo zunanjega svetovalca za izvedbo organizacijskih sprememb na področju menedžmenta?

Namen: Preučiti značilnosti in vlogo zunanjih svetovalcev pri uvajanju organizacijskih sprememb na področju menedžmenta.

Metoda: Opravili smo sistematično meta analizo domače in tuje strokovne literature. Literaturo smo izbirali preko javno dostopnih bibliografskih baz podatkov Web of science, Elsevier, Jstor, Emerald. Uporabili smo naslednje ključne besede: Organizational Change, Consultant, Management, Introduction of changes, Process, Consultancy industry.

Rezultati: Glede na ugotovitve iz naklonjenosti do svetovanja na področju menedžmenta povzamemo (Kubr, 2002, Jang \& Lee, 1998, Furusten, 2013, Canato \& Giangreco, 2011), da je svetovanje smiselno $\mathrm{v}$ primerih, ko organizacija potrebuje hiter dostop do specifičnih znanj: strateškega upravljanja, informacijske tehnologije, finančnega upravljanja, trženja in distribucije, eposlovanje, upravljanja človeških virov, upravljanja znanja, produktivnosti in upravljanja uspešnosti, upravljanja celotne kakovosti. Ne strinjajo se vsi (Bloomfield \& Danieli, 1995, Phelan, 2013), da za zgoraj navedena področja res potrebujemo svetovanje. Glede na ugotovitve iz kritičnih stališč do svetovanja na področju menedžmenta je možno povzeti splošno ugotovitev, da je storitev svetovanja neoprijemljiva in je izide težko napovedati. Menedžerji naj bi večinoma ravnali v svojem interesu pri uvajanju svetovanja v organizacijo (Whittle, 2006, Leiby, 2018). Avtorja (Grint \& Case, 1998) navajata visok odstotek neuspehov svetovalnih projektov, saj $70 \%$ projektov svetovalnega menedžmenta propade.

Organizacija: V organizaciji je nenehno potreben poglobljen razmislek o tem, ali pri uvajanju izbranih sprememb potrebujejo zunanjega svetovalca.

Družba: Napredek in uspeh je v organizaciji možno dosegati brez zunanjih strokovnjakov in novih pristopov, z uporabo načela »zdrave kmečke pameti«. S tem načelom naj bi posvečali implementacije te modrosti v svoje procese menedžmenta.

Originalnost: V ugotovitvah izpostavimo ključne dejavnike, ki naj bi jih upoštevali pri uvedbi organizacijskih sprememb na področju menedžmenta.

Omejitve/nadaljnje raziskovanje: Ugotovitve raziskave temeljijo na teoretičnih spoznanjih izbranih avtorjev iz področja organizacijskih sprememb na področju menedžmenta, medtem ko naj bi v nadaljnjem raziskovanju opravili empirično raziskavo.
\end{abstract}

Ključne besede: menedžment, organizacija, proces, spremembe, svetovalec, svetovalna dejavnost, uvajanje sprememb. 


\section{Uvod}

Negotovost je normalno človeško stanje, ki ima vzrok v pomanjkanju vzvodov za določitev razvoja izbranega dogodka. Czarniawska (2013, str. 11) ugotavlja, da ima iz organizacijskega vidika negotovost slabšalni pomen in v organizacijah naj bi si nenehno prizadevali za njeno zmanjšanje. Eden izmed možnih načinov, kako zmanjšati negotovost v organizacijah, je najem zunanjih svetovalcev. Svetovalci za organizacijske spremembe naj bi bili v sodobnem poslovnem okolju organizacij zelo razširjeni in vedno bolj prisotni. V zadnjih treh desetletjih v vse več organizacijah povprašujejo in uporabljajo storitve zunanjih ponudnikov različnih oblik menedžerskega strokovnega znanja in veščin. Vsebine storitev svetovalnih organizacij predstavljajo strokovno področje, ki ga je težko določiti in izmeriti, kot npr. težko je ovrednotiti - tudi po že izvedeni storitvi - kaj je bilo dejansko doseženo. Osnovna težava naj bi bila v tem, da uporabniki storitev ne vedo natančno, kaj naj bi potrebovali. Zaradi tega spoznanja uporabniki storitev najamejo zunanje svetovalce, ki naj bi vedeli, kaj ponujajo. Kljub temu v organizacijah naročajo svetovalne storitve in jih drago plačujejo, brez jamstva, da bodo dobili zadostno dodano vrednost za njihovo naložbo.

Glavna področja zunanjih svetovalcev so: splošni in strateški menedžment, informacijskokomunikacijska tehnologija, menedžment financ, trženje, elektronsko poslovanje, menedžment človeških virov, menedžment znanja, produktivnost in menedžment uspešnosti, menedžment celovite kakovosti in preoblikovanje podjetja (Kubr, 2002, str. 272). Tavoletti, Cerruti \& Grieco (2013, str. 903) ugotavljajo, da v organizacijah ob najemu zunanjih svetovalcev pričakujejo, da bodo izboljšali uspešnost, razrešili težave in poiskali nove in boljše načine za izvajanje njihove dejavnosti.

$\mathrm{V}$ prispevku so predstavljeni izidi iz analize strokovne literature, $\mathrm{v}$ kateri so avtorji obravnavali svetovanje pri spremembah $\mathrm{v}$ organizacijah. $\mathrm{V}$ ta namen smo opravili sistematičen pregled domače in tuje strokovne literature, ki nam je bila dostopna preko treh izbranih svetovnih baz podatkov. V rezultatih so predstavljene prednosti in slabosti svetovalnih storitev na področju menedžmenta ter prikazana področja, na katerih je najem zunanjega svetovalca koristen, in področja, na katerih ni. V zaključku utemeljimo prispevek k organizacijski znanosti, navedemo predpostavke in omejitve ter izpostavimo možnosti za nadaljnje raziskovanje.

\section{Teoretična izhodišča}

Zaradi vedno večje specializacije proizvodov, procesov in postopkov v podjetjih ter drugih ustanovah, ki so posledica rastoče konkurenčnosti na sodobnem tržišču, se podjetja ne zmorejo dovolj hitro odzivati na nove izzive. V podjetjih in drugih ustanovah si vedno izraziteje pomagajo z zunanjimi svetovalnimi storitvami, da bi ohranili ustrezno strokovno znanje in veščine ter sledili hitrim spremembam na področju tehnično-tehnološkega in družbenega razvoja. 
Svetovanje za uvajanje organizacijskih sprememb je načrtovan, organiziran, voden in kontroliran poseg $\mathrm{v}$ izbrano organizacijo, in sicer $\mathrm{z}$ namenom, da bi najprej prepoznali razloge za spreminjanje $\mathrm{v}$ trenutnem načinu njenega delovanja. Identificiranju razlogov za trenutno stanje naj bi sledil nabor možnih aktivnosti, ki so namenjene izboljševanju prepoznanih težav Soriano (2005, str. 35). V MCA (Management Consultancies Association Ltd) definirajo svetovanje kot ,ustvarjanje vrednosti za organizacije z izboljšanjem uspešnosti, doseženo z uveljavljanjem objektivnih nasvetov in implementacijo svetovanih poslovnih razrešitev" (www.mca.org.uk).

Empson \& Gond (2020, str. 121) opredeljujeta svetovanje kot posebno storitev, ki jo svetovalci nudijo organizacijam preko posebej usposobljenih oseb, ki naj bi na objektiven in neodvisen način pomagali strankam ali organizacijam pri prepoznavanju težav menedžmenta, analiziranju teh težav in priporočali razrešitve za te težave. Brandi \& Elkjaer (2019, str. 186) predstavljajo svetovanje kot eden izmed razpoložljivih načinov za deljenja znanja in veščin (kompetenc). V svetovalnih podjetjih praviloma delujejo in vzdržujejo stike v različnih dejavnostih, izkoriščajo raznoliko znanje in veščine ter jih uporabljajo v nenehno spreminjajočem se gospodarskem in družbenem okolju. Po SSJK (fran.si/130/sskj-slovar-slovenskega-knjiznega-jezika) svetovati pomeni izražati svoje mnenje o tem, kako naj kdo, zlasti v neprijetnem, neugodnem položaju, ravna ali dela.

Furusten (2013, str. 278) navaja, da, znanja in veščin, potrebnih za svetovanje organizacijam, ni mogoče določiti črno-belo in jih zato ni mogoče pridobiti iz knjig in drugih virov. Svetovalci s pravim znanjem in izkušnjami naj bi intuitivno vedeli, kako naj bi obvladovali svetovalni proces. Težko naj bi bilo tudi slediti izvoru znanj in veščin, ki jih v svetovalnih podjetjih in drugih ustanovah pridobivajo z izkušnjami, ker se v praksi nenehno učijo novih stvari. Bronnenmayer, Wirtz \& Göttel (2016, str. 710-717) navajajo naslednje glavne gradnike uspešnega svetovanja: skupna vizija med svetovalcem in stranko, intenzivno sodelovanje, medsebojno zaupanje, visoko soglasje o potrebnih virih in podpora poslovodstva (vršnih menedžerjev) svetovalcem. Leiby (2018, str. 2) navaja, da naj bi vršni menedžerji večinoma ravnali v svojem interesu pri načrtovanju in izvajanju zunanjega svetovanja. Celotno svetovanje naj bi vršni menedžerji obvladovali in usmerjali na način, s pomočjo katerega naj bi zagotavljali, da so bile njihove odločitve $\mathrm{v}$ dani situaciji upravičene ter tako ohranili vtis kakovostne izbire zunanjega svetovanja.

Canato \& Giangreco (2011, str. 235) menita, da svetovalci z izpostavljenostjo različnim izkušnjam pri svojem delu delujejo kot »opraševalci«, ki prenašajo in širijo znanje ter veščine $\mathrm{z}$ ene stranke na drugo. To ima pozitivne učinke za njihove stranke, ki prek svetovalcev dostopajo do najbolj kakovostnih znanj in veščin. Stardy (2011, str. 526) navaja, da svetovalec $\mathrm{s}$ svojim pristopom oblikuje, formalizira in legitimira naravo organizacijskih sprememb. Canato \& Giangreco (2011, str. 233-235) sta opravila pregled strokovne literature in ugotovila štiri glavne vloge svetovalcev, ki jim jih pripisujejo avtorji: svetovalec kot vir informacij, svetovalec kot vodič za standardizacijo, svetovalec kot posrednik znanja in veščine ter svetovalec kot 
povezovalec znanja in veščin. Pinault (2000, str. 3) pa svetovalce opisuje slabšalno kot brezpilotne zrakoplove, kanibale, ki jim ni mar za ljudi, mojstre leporečja, vohune in ponarejevalce podatkov, izvajalce groženj in oportuniste, strokovnjake za »nizke udarce« ipd. Trdi, da niso strokovnjaki v nobeni dejavnosti, ampak promotorji lastnega interesa.

Pri svetovanju za uvajanje organizacijskih sprememb naj bi šlo tudi za velike zaslužke, kar omenjajo različni avtorji in viri. Npr. Craig (2005, str. 7) ocenjuje, da je obseg letne svetovne svetovalne dejavnosti cca 60 milijard funtov (100 milijard dolarjev). V Veliki Britaniji naj bi npr. v podjetjih in vladi vsak teden plačali več kot 150 milijonov funtov za svetovalne storitve na področju menedžmenta, kar je 30 milijonov funtov na delovni dan. Czerniawska \& May (2004, str. 7) navajata, da so v zadnjih 10 letih, prihodki 40 največjih svetovalnih podjetij na svetu, iz 17 milijard dolarjev narasli na več kot 82 milijard dolarjev. Po podatkih FEACO (European Federation of Management Consulting Associations) naj bi evropski prihodek podjetij, ki se ukvarjajo z menedžerskim svetovanjem, rasel hitreje kot evropski bruto družbeni proizvod (BDP); v povprečju 6,4 \% v primerjavi z 2,2 \% (FEACO, 2017). V istem obdobju naj bi zaposlovanje evropskih svetovalcev s področja menedžmenta naraščalo hitreje kot skupno evropsko zaposlovanje: v povprečju $6 \%$ v primerjavi z $0,8 \%$. (Cerruti, Tavoletti \& Grieco, 2019, str. 903).

Clark \& Kipping (2012, str. 56) ugotavljata, da se je sodobno svetovanje s področja menedžmenta začelo razvijati v začetku dvajsetih let prejšnjega stoletja. Furusten (2013, str. 266) ugotavlja, da se je od svetovalcev na področju menedžerskih znanj in veščin pričakovalo, da so obvladovali organizacije, kar je pomenilo razreševanje zapletenih menedžerskih naloge in vlog. Butler \& Collins (2016, str. 55) predlagata ustvarjanje „registra svetovalcev za menedžment in industrijske svetovalce“, s pomočjo katerega bi omogočali potencialnim naročnikom vpogled v ustrezno ponudbo svetovanja. Primarni namen registra naj bi bil v zagotavljanju kakovost storitev strankam s sistemom prostovoljne registracije in $\mathrm{s}$ tem izključitev neuglednih svetovalnih organizacij ter posameznikov s tržišča. Whittle (2006, str. 426) navaja, da naj bi svetovalci za menedžment uporabljali različne manipulativne tehnike, s pomočjo katerih pomirijo svoje potencialne stranke, ki se soočajo s precejšnjo mero negotovosti pri presojanju razmerja med stroški in strokovnim znanjem ter veščinami svetovalcev. Odločitev za najem svetovalne organizacije oz. svetovalcev za menedžment naj bi slonela na prepričanju naročnika, da so njihove težave posledica slabe strategije ali toge organizacijske strukture, neprimernih poslovno-organizacijskih sistemov ali pomanjkanja strokovnega znanja in veščin.

Poleg pozitivnih učinkov svetovalcev na področju menedžmenta za organizacije se pojavljajo tudi negativna mnenja in stališča. Craig (2005, str. 101) navaja, da naj bi bili resnični vzroki za težave v slabem menedžmentu ali pomanjkanju kohezije v menedžerskem timu, kar naj bi vodilo v nenehno nesoglasje med različnimi organizacijskimi enotami (npr. referati, službami, sektorji ipd.). Tovrstnih težav naj ne bi bilo mogoče razreševati z najemom svetovalca za menedžment. Svetovalec za menedžment ne more razreševati npr. slabe strategije, neprimerne 
organizacijske strukture ali napačnega tržnega pristopa, temveč odpravlja neustrezno vodenje. Nekateri kritiki menedžerskega svetovanja, kot je npr. Phelan (2013, str. 4), opozarjajo, da svetovalci za menedžment prepričujejo poslovni svet, da so podjetja racionalne tvorbe in jih je mogoče obvladovati na podlagi številk ter da bodo njihovi modeli in teorije zagotavljali podrobna navodila tem podjetjem, kako uspeti. $\mathrm{V}$ podjetjih poskušajo te modele in teorije uveljavljati, vendar neuspešno, saj podjetja niso racionalne tvorbe. Razlog za neuspešno uveljavljanje novih modelov in teorij naj bi bil v ljudeh, ki ta podjetja vodijo. Podobno, kot navaja Craig, naj težava ne bi bil v modelih in teorijah, ampak v poslovodstvu, ki trenutno vodi neuspešno organizacijo. Kitay \& Wright (2004, str. 1) ugotavljata, da so kritike svetovalcev na področju menedžmenta vse pogostejše in da temeljijo na trditvah o izkoriščanju nemoči menedžerjev zaradi negotovosti $\mathrm{v}$ zvezi $\mathrm{z}$ njihovo kariero, delovno vlogo in okoljem organizacije. To nemoč naj bi svetovalci s področja menedžmenta s svojimi idejami in nasveti samo še spodbujali.

Po pregledu teoretičnih izhodišč o svetovanju, svetovalnih storitvah in svetovanju s področja menedžmenta in svetovalcev na področju menedžerskih znanj in veščin smo ugotovili, da je tematika aktualna ter vredna pozornosti teoretikov, raziskovalcev in praktikov. Ker doslej še ni bilo na enem mestu podanih konkretnih informacij o značilnostih in vlogi zunanjih svetovalcev pri uvajanju sprememb na področju menedžmenta, smo to identificirali kot raziskovalno vrzel. $\mathrm{V}$ ta namen smo formirali raziskovalno vprašanje in po treh izbranih bazah podatkov opravili sistematičen pregled strokovne literature o svetovanju in svetovalcih na področju menedžmenta pri uvajanju organizacijskih sprememb.

\section{Metoda}

Namen prispevka je bil preučiti značilnosti in vlogo zunanjih svetovalcev na področju menedžmenta pri uvajanju organizacijskih sprememb v podjetju ali v drugi ustanovi. V članku smo uporabili smernice integrativnega pregleda. Raziskavo smo izvedli $\mathrm{v}$ treh bazah znanstvenih člankov Web of science, Elsevier, Jstor, Emerald. Ključne besedne zveze, ki smo jih uporabili pri iskanju, so bile: »organizacijske spremembe (Organizational Change), »svetovalni menedžment« (Consultant, Management), »uvajanje sprememb« (Introduction of changes), »proces« (Process) in »industrija svetovalnega menedžmenta« (Consultancy industry) (Slika 1). 


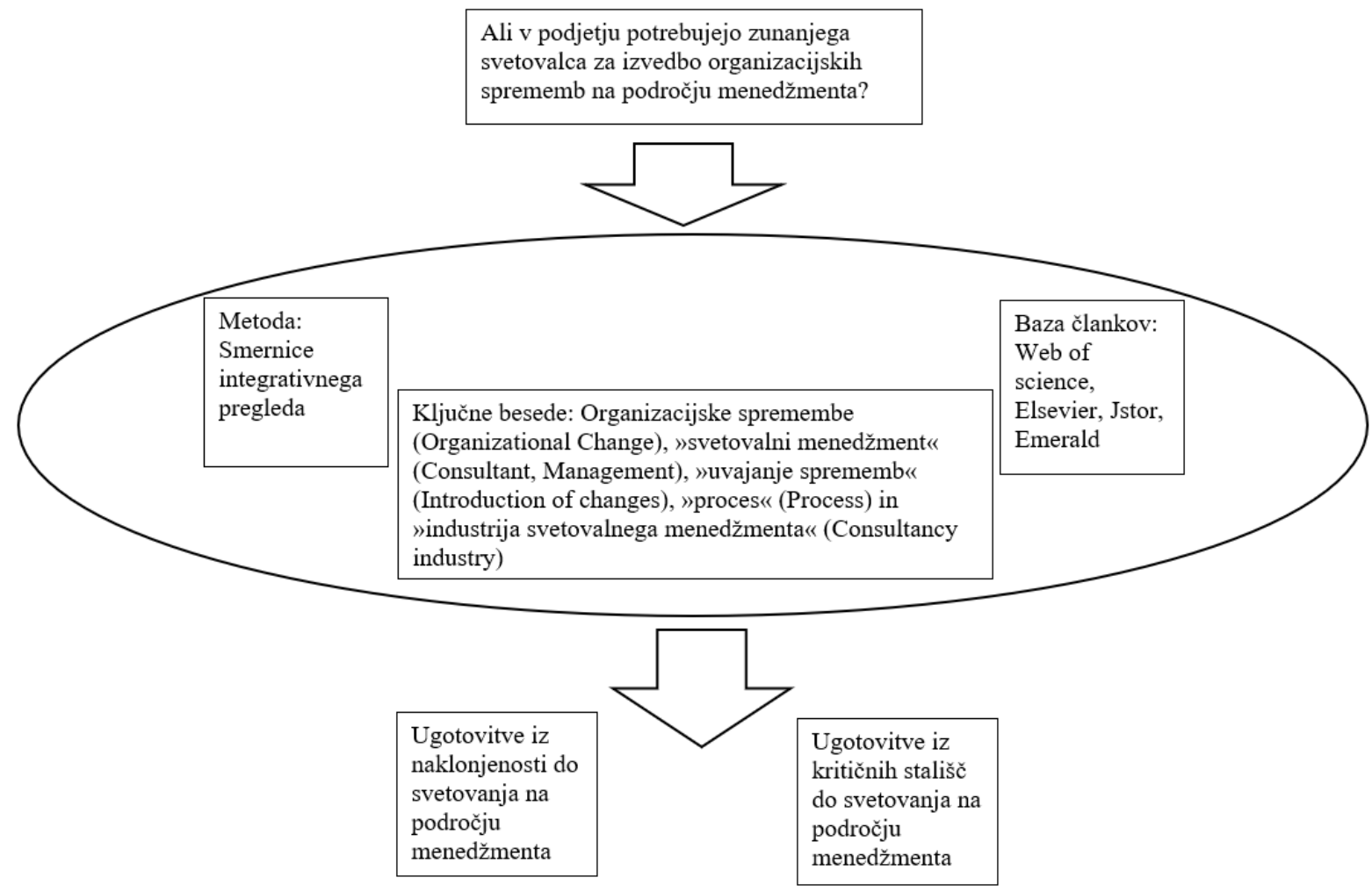

Slika 1. Model raziskave

\section{Rezultati in razprava}

Fokusirali smo se na prispevke, ki govorijo o dveh vidikih menedžerskega svetovanja: kaj je potrebno za uspešno svetovanje in glavne kritike menedžerskega svetovanja. Časovno obdobje, iz katerega smo izbirali članke (1978-2020), zajema čas naglega porasta menedžerskega svetovanja $\mathrm{v}$ svetu, ki se je začel konec osemdesetih let dvajsetega stoletja in doživlja kulminacijo v sodobnem času. Potek redukcije preučevanega gradiva je prikazan na sliki 2. Najprej smo med zadetki, ki jih je bilo 4.801, izbrali tiste ki so bili glede na naslov najbližji naši raziskavi. Na ta način smo izbrali 325 naslovov, pri katerih smo prebrali izvleček (abstract) in se odločali, ali članek obdržimo ali ne. Glede na vsebino ujemanja izvlečka (abstract) smo se omejili na podrobnejši pregled 41 bibliografskih enot. 


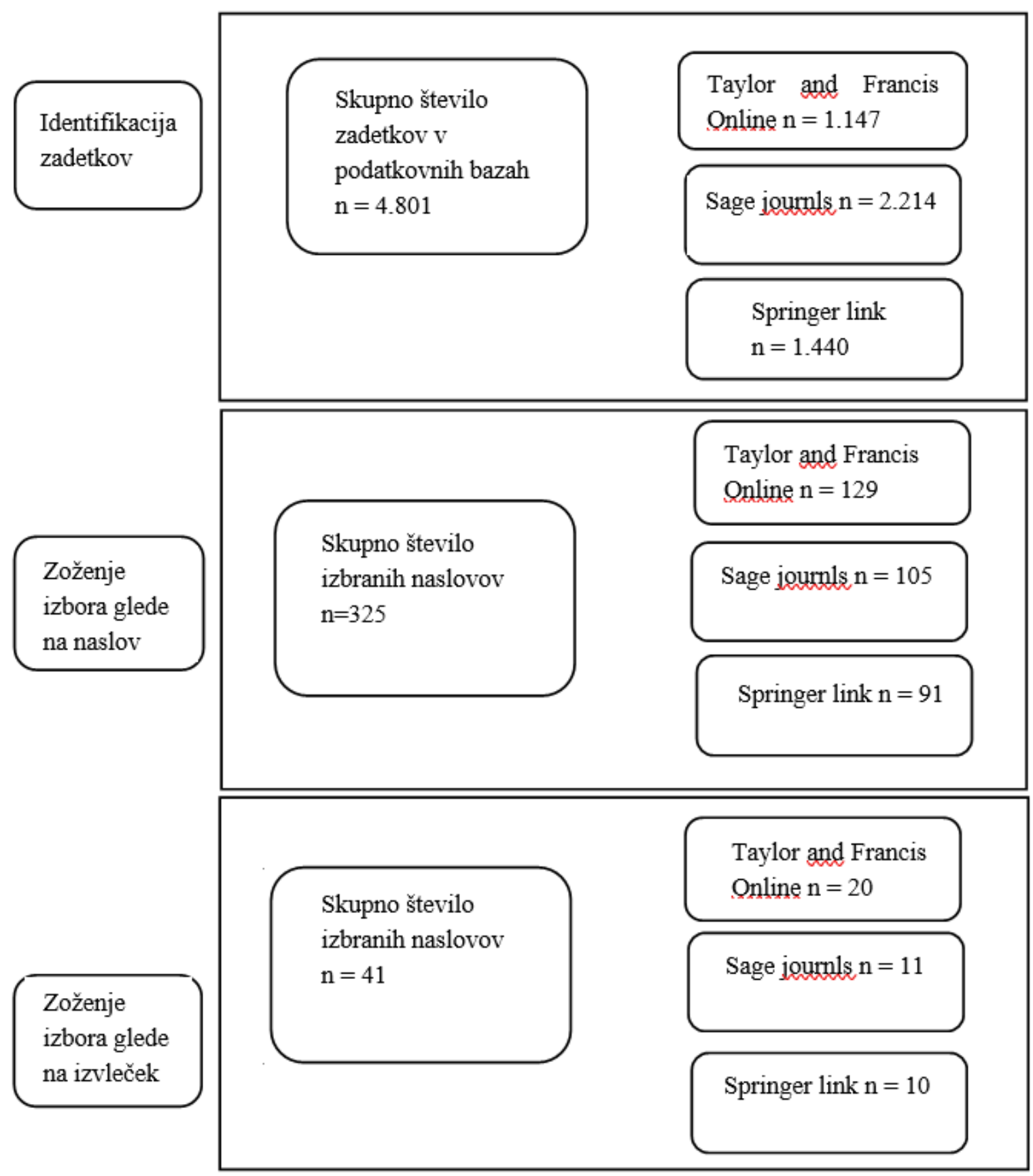

Slika 2. Rezultati pregleda literature po metodologiji Prisma

V tabeli 1 smo predstavili mnenja preučevanih avtorjev. Pri tem smo povzemali njihov odnos do menedžerskega svetovanja. Na podlagi tega smo ocenjevali njihov odnos do našega raziskovalnega vprašanja, ali organizacija potrebuje zunanjega svetovalca za izvedbo organizacijskih sprememb? V prvem stolpcu smo predstavili avtorja in letnico, v drugem naslov publikacije in $\mathrm{v}$ tretjem povzetek avtorjevega članka. 
Tabela 1. Mnenja preučevanih avtorjev

\begin{tabular}{|c|c|c|}
\hline Avtor, letnica & Naziv publikacije & Mnenje avtorja \\
\hline Alvesson, M. (1993) & $\begin{array}{l}\text { Organizations As Rhetoric: } \\
\text { Knowledge-Intensive Firms And } \\
\text { The Struggle With Ambiguity }\end{array}$ & $\begin{array}{l}\text { Svetovanje - sposobnost prilagajanja } \\
\text { novim situacijam }\end{array}$ \\
\hline $\begin{array}{l}\text { Bloomfield, B. P., \& } \\
\text { Danieli, A. (1995) }\end{array}$ & $\begin{array}{l}\text { The Role Of Management } \\
\text { Consultants In The Development } \\
\text { Of Information Technology: The } \\
\text { Indissoluble Nature Of Socio- } \\
\text { Political And Technical Skills }\end{array}$ & $\begin{array}{l}\text { Dvojna slika svetovalcev: vir znanja in } \\
\text { šarlatanstvo }\end{array}$ \\
\hline $\begin{array}{l}\text { Brandi, U., \& Elkjaer, B. } \\
\text { (2019) }\end{array}$ & $\begin{array}{l}\text { Subtleties of knowledge sharing- } \\
\text { Results from a case study within } \\
\text { management consultancy }\end{array}$ & $\begin{array}{l}\text { Svetovanje kot način kako distribuirati in } \\
\text { širiti znanje }\end{array}$ \\
\hline $\begin{array}{l}\text { Bronnenmayer, M., Wirtz, } \\
\text { B.W. and Göttel, V. } \\
(2016)\end{array}$ & $\begin{array}{l}\text { Determinants of perceived } \\
\text { success in management } \\
\text { consulting: An empirical } \\
\text { investigation from the consultant } \\
\text { perspective. }\end{array}$ & $\begin{array}{l}\text { Glavne gradniki uspeha svetovanja: } \\
\text { skupna vizija med svetovalcem in stranko, } \\
\text { intenzivno sodelovanje, medsebojno } \\
\text { zaupanje, visoko soglasje o potrebnih virih } \\
\text { in podpora najvišjega vodstva svetovalcem. }\end{array}$ \\
\hline $\begin{array}{l}\text { Butler, N., \& Collins, D. } \\
\text { (2016) }\end{array}$ & $\begin{array}{l}\text { The failure of consulting } \\
\text { professionalism? A longitudinal } \\
\text { analysis of the Institute of } \\
\text { Management Consultants }\end{array}$ & $\begin{array}{l}\text { predlagajo ustvarjanje „register } \\
\text { svetovalcev za poslovodstvo in } \\
\text { industrijske svetovalce“ } \text { - način kako } \\
\text { povečati strokovnost }\end{array}$ \\
\hline $\begin{array}{l}\text { Canato, A., \& Giangreco, } \\
\text { A. }(2011)\end{array}$ & Gurus or Wizards? & $\begin{array}{l}\text { Svetovalci delujejo kot »opraševalci«, ki } \\
\text { lahko prenašajo in širijo znanje z ene } \\
\text { stranke na drugo }\end{array}$ \\
\hline $\begin{array}{l}\text { Clark, T., \& Kipping M. } \\
\text { (2012) }\end{array}$ & $\begin{array}{l}\text { The Oxford Handbook of } \\
\text { Management Consulting }\end{array}$ & $\begin{array}{l}\text { Znanstveni menedžment ni imel glavnega } \\
\text { vpliva na razvoj svetovalnih podjetij }\end{array}$ \\
\hline $\begin{array}{l}\text { Clark, T., \& Salaman, G. } \\
\text { (1998) }\end{array}$ & $\begin{array}{l}\text { Creating the "Right" Impression: } \\
\text { Towards a Dramaturgy of } \\
\text { Management Consultancy }\end{array}$ & $\begin{array}{l}\text { Primerjata delo svetovalcev za menedžment } \\
\text { z nastopom igralcev v gledališču }\end{array}$ \\
\hline Craig, D. (2005) & $\begin{array}{l}\text { The scandalous inside story of } \\
\text { the management consulting } \\
\text { money machine }\end{array}$ & $\begin{array}{l}\text { Svetovna poslovna svetovalna industrija na } \\
\text { leto vredna okoli } \mathbf{6 0} \text { milijard funtov }\end{array}$ \\
\hline Czarniawska, B. (2013) & The Uncertainties of Consulting & $\begin{array}{l}\text { Svetovanje kot način kako zmanjšati } \\
\text { negotovost v organizacijah }\end{array}$ \\
\hline Dunford, R. (2000) & $\begin{array}{l}\text { Key challenges in the search for } \\
\text { the effective management of } \\
\text { knowledge in management } \\
\text { consulting firms }\end{array}$ & $\begin{array}{l}\text { Svetovalci z leti naberejo dragocena } \\
\text { znanja }\end{array}$ \\
\hline $\begin{array}{l}\text { Fincham, R., \& Clark, T. } \\
(2002)\end{array}$ & $\begin{array}{l}\text { Preface: Management } \\
\text { Consultancy: Issues, } \\
\text { Perspectives, and Agendas }\end{array}$ & $\begin{array}{l}\text { Želja za kontrolom nad razmišljanjem in } \\
\text { delovanjem managerjev }\end{array}$ \\
\hline Fincham, R. (2002) & $\begin{array}{l}\text { The Agent's Agent: Power, } \\
\text { Knowledge, and Uncertainty in } \\
\text { Management Consultancy }\end{array}$ & Svetovalci kot "agenti" lastnikov kapitala \\
\hline
\end{tabular}


Revija za univerzalno odličnost / Journal of Universal Excellence,

Junij / June 2021, leto / year 10, številka / number 2, str. / pp. 108-122.

»nadaljevanje «

Furusten, S. (2013)

Commercialized professionalism

Reševanje zapletenih menedžerskih nalog

on the field of management

consulting

\begin{tabular}{lll}
\hline Grint, K., \& Case, P. & $\begin{array}{l}\text { The Violent Rhetoric of Re- } \\
\text { engineering: Management } \\
\text { Consultancy on the Offensive }\end{array}$ & $\begin{array}{l}\text { Približno 70 \% projektov svetovalnega } \\
\text { menedžmenta propadajo }\end{array}$
\end{tabular}

Consultancy on the Offensive

Jang, Y., \& Lee, J. (1998) Factors influencing the success of Strokovnjaki na določenih področjih management consulting projects

\begin{tabular}{lll}
\hline $\begin{array}{l}\text { Kitay, J., \& Wright, C. Take the money and run? } \\
\text { (2004) }\end{array}$ & $\begin{array}{l}\text { Strokovnjak, prerok, partner, poslovnež in } \\
\text { uslužbenec }\end{array}$
\end{tabular}
(2004) uslužbenec

Kubr, M. (2002) Management Consulting: A

Guide to the Profession,

Glavna področja delovanja svetovalnih

International

strokovnjakov so splošno in strateško upravljanje, informacijska tehnologija, finančno upravljanje, trženje in distribucija, e-poslovanje, upravljanje človeških virov, upravljanje znanja, produktivnost in upravljanje uspešnosti, upravljanje celotne kakovosti

Law, M. (2009) Managing consultants.
Svetovanje lahko v mnogih primerih prinese veliko korist naročnikom in celotnim panogam $\mathrm{v}$ gospodarstvu

\begin{tabular}{ll}
\hline Leiby, J. (2018) & The role of consultants and \\
& management prestige in \\
& management control system \\
adoption.
\end{tabular}

Menedžerji večinoma ravnajo v svojem interesu pri izvajanju svetovanja

\begin{tabular}{ll}
\hline McLachlin, R.D. (1999) & $\begin{array}{l}\text { Factors for consulting } \\
\text { engagement success }\end{array}$
\end{tabular}
engagement success
Integriteta svetovalcev, vključenost stranke in pripravljenost na spremembe, jasen dogovor glede zahtev in pričakovanj, nadzor stranke nad angažmajem z jasnimi in omejenimi nalogami in usposobljenost svetovalca

\begin{tabular}{lll}
\hline McKenna, C. (2006) & $\begin{array}{l}\text { Factors for consulting } \\
\text { engagement success }\end{array}$ & $\begin{array}{l}\text { Svetovanje izvira iz dvajsetih let prejšnjega } \\
\text { stoletja }\end{array}$ \\
\hline $\begin{array}{l}\text { Menon, T., \& Pfeffer, J. } \\
(2003)\end{array}$ & $\begin{array}{l}\text { Valuing Internal vs. External } \\
\text { Knowledge: Explaining the } \\
\text { Preference for Outsiders }\end{array}$ & $\begin{array}{l}\text { Zunanje znanje - Predstava da je zunanje } \\
\text { znanje bolj dragoceno od notranjega }\end{array}$ \\
\hline $\begin{array}{l}\text { Mosonyi, S., Empson, L. } \\
\text { and Gond, JP. (2020) }\end{array}$ & $\begin{array}{l}\text { Management Consulting: } \\
\text { Towards anIntegrative } \\
\text { Framework of } \\
\text { Knowledge,Identity, and Power }\end{array}$ & $\begin{array}{l}\text { Svetovalci na objektiven in neodvisen } \\
\text { način pomagajo strankam ali organizacijam } \\
\text { pri prepoznavanju problemov vodenja }\end{array}$ \\
\hline $\begin{array}{l}\text { Nees, D. B., \& Greiner, L. } \\
\text { E. (1985) }\end{array}$ & $\begin{array}{l}\text { Seeing behind the look-alike } \\
\text { management consultants }\end{array}$ & $\begin{array}{l}\text { Storitev svetovanja je neoprijemljiva, } \\
\text { rezultate je težko napovedati }\end{array}$ \\
\hline Phelan, K. (2013) & $\begin{array}{l}\text { I am Sorry, I Broke Your } \\
\text { Company }\end{array}$ & $\begin{array}{l}\text { Težava je v nesposobnih ljudeh ki vodijo } \\
\text { organizacijo }\end{array}$
\end{tabular}


Pinault, L. (2000) Consulting Demons: Inside the Unscrupulous World of Global Corporate Consulting svetovalce opisuje kot brezpilotne zrakoplove, kanibale katerim ni mar za ljudi, mojstre pretvarjanja, vohune in falzifikatorje podatkov

\begin{tabular}{ll}
\hline Schein, E. H. (1978) & $\begin{array}{l}\text { The Role of the Consultant: } \\
\text { Content Expert or Process } \\
\text { Facilitator? }\end{array}$ \\
\hline Singleton, A. (2012) & $\begin{array}{l}\text { How to Choose an Agency or } \\
\text { Consultant }\end{array}$
\end{tabular}

Soriano, D. R. (2004) External consultants in organisations: evaluating the Spanish case

\section{Dva modela svetovanja: model katalizatorja in model pospeševalnika}

\section{Prednosti zunanjih svetovalcev: fleksibilnost, pridobitev strokovnega znanja in dodatnih idej v organizacijo}

\begin{tabular}{lll}
\hline Sturdy, A. (1997) & $\begin{array}{l}\text { The Consultancy Process - An } \\
\text { Insecure Business? }\end{array}$ & $\begin{array}{l}\text { Naročnik svetovanja kot žrtev } \\
\text { brezobzirnih svetovalcev }\end{array}$ \\
\hline $\begin{array}{l}\text { Tavoletti, E., Cerruti, C., } \\
\text { \& Grieco, C. (2019) }\end{array}$ & $\begin{array}{l}\text { Management consulting: a review } \\
\text { of fifty years of scholarly } \\
\text { research. }\end{array}$ & $\begin{array}{l}\text { Naročnik pričakuje, da bo izboljšal svojo } \\
\text { uspešnost, rešil svoje težave in poiskal } \\
\text { nove in boljše načine za svoje početje }\end{array}$ \\
\hline $\begin{array}{l}\text { Van Nistelrooij, A., De } \\
\text { Caluwé, L., \& Schouten, } \\
\text { N. (2007) }\end{array}$ & $\begin{array}{l}\text { Management Consultants' } \\
\text { Colourful Ways of Looking at } \\
\text { Change: An Explorative Study } \\
\text { under Dutch Management } \\
\text { Consultants. }\end{array}$ & Metode, ki vnaprej jasno določajo rezultate \\
\hline $\begin{array}{l}\text { Werr, A., Stjernberg, T., } \\
\text { \& Docherty, P. (1997) }\end{array}$ & $\begin{array}{l}\text { The functions of methods of } \\
\text { change in management } \\
\text { consulting }\end{array}$ & Osredotočanje na organizacijo kot celoto \\
\hline $\begin{array}{l}\text { Wickham, L., \& Wilcock } \\
\text { J. (2016) }\end{array}$ & $\begin{array}{l}\text { Management consulting: } \\
\text { delivering an effective project }\end{array}$ & $\begin{array}{l}\text { Ustvarjanje vrednosti za organizacije z } \\
\text { izboljšanjem uspešnosti }\end{array}$ \\
\hline $\begin{array}{l}\text { Williams A.P.O., } \\
\text { Woodward S. (1994) }\end{array}$ & Consultancy Roles. & $\begin{array}{l}\text { Svetovalci znotraj organizacije } \\
\text { Whittle, A. (2006) }\end{array}$ \\
\hline $\begin{array}{l}\text { The paradoxical repertoires of } \\
\text { management consultancy }\end{array}$ & $\begin{array}{l}\text { Svetovalci za menedžment uporabljajo } \\
\text { različne manipulativne tehnike }\end{array}$ \\
\hline
\end{tabular}

Večina avtorjev (Werr, Stjernberg \& Docherty, 1997, McLachlin, 1999, Bronnenmayer, Wirtz \& Göttel, 2016) se strinja, da so glavni gradniki upeha svetovalnega procesa: skupna vizija med svetovalcem in stranko, intenzivno sodelovanje, medsebojno zaupanje, visoko soglasje o potrebnih virih in podpora najvišjega poslovodstva svetovalcem.

Avtorji (Kubr, 2002, Tavoletti, Cerruti \& Grieco, 2019) poudarjajo glavna področja delovanja svetovalnih strokovnjakov: splošni in strateški menedžment, informacijsko-komunikacijska tehnologija, menedžment financ, trženje in distribucija, e-poslovanje, menedžment človeških virov, menedžment znanja, produktivnost in menedžment uspešnosti, menedžment celovite 
kakovosti. Ne strinjajo se vsi (Bloomfield \& Danieli, 1995, Phelan, 2013), da za zgoraj navedena področja res potrebujemo svetovanje. Verjetno je res, da $\mathrm{v}$ organizaciji, kjer menedžerji ne obvladajo npr. produktivnosti, zunanjemu svetovalcu ne bo s» čarobno palico« uspelo tega spremeniti. V takšnem primeru je podjetju ustrezneje, da zaposli menedžerja, ki razume, kaj to pomeni produktivnost in poti za njeno izboljšanje. To se nam zdi trajnejša razrešitev kot denimo začasno svetovanje $\mathrm{z}$ negotovim izidom. Kritiki najemanja svetovalcev (Phelan, 2013, Craig, 2005) omenjajo prav nesposobnost menedžmenta v neki organizaciji, da razrešuje sprotne probleme. $Z$ najemom svetovalcev pa lastnik samo podaljšuje agonijo take organizacije. Drugače je, če organizacija potrebuje strokovno pomoč iz področja, ki ga ne pokriva oziroma je novo za organizacijo, kot je to npr. digitalizacija, robotizacija, postavitev novih tehnologij in podobno.

Druga skupina kritikov svetovalcev za menedžment (Pinault, 2000, Clark \& Salaman, 1998, Sturdy, 1997) primerja svetovalce z nastopom igralcev v gledališču, pripisuje jim šarlatanstvo, naročnika svetovanja prikazuje kot žrtev brezobzirnih svetovalcev, svetovalce opisuje kot brezpilotne zrakoplove in kanibale, ki jim ni mar za ljudi, mojstre pretvarjanja in falzifikatorje podatkov.

Glede na ugotovitve iz naklonjenosti do svetovanja na področju menedžmenta povzamemo (Kubr, 2002, Jang \& Lee, 1998, Furusten, 2013, Canato \& Giangreco, 2011), da je svetovanje smiselno v primerih, ko organizacija potrebuje hiter dostop do specifičnih znanj: strateškega upravljanja, informacijske tehnologije, finančnega upravljanja, trženja in distribucije, eposlovanje, upravljanja človeških virov, upravljanja znanja, produktivnosti in upravljanja uspešnosti, upravljanja celotne kakovosti. To so vsekakor področja za katera je pametno razmisliti o angažiranju zunanjega svetovalca. $V$ odvisnosti od hitrosti s katero želimo uvajati določene spremembe, lahko se organizacija odloči za graditev lastnega strokovnjaka za želeno področje. To pride v poštev če imamo dovolj časa na razpolago, kar je prej izjema kot pravilo $\mathrm{v}$ sodobnem poslovnem okolju.

Glede na ugotovitve iz kritičnih stališč do svetovanja na področju menedžmenta je možno povzeti splošno ugotovitev, da je storitev svetovanja neoprijemljiva in je izide težko napovedati. Menedžerji naj bi večinoma ravnali v svojem interesu pri uvajanju svetovanja $\mathrm{v}$ organizacijo (Whittle, 2006, Leiby, 2018). Avtorja (Grint \& Case, 1998) navajata visok odstotek neuspehov svetovalnih projektov, saj $70 \%$ projektov svetovalnega menedžmenta propade.

Glede na naše raziskovalno vprašanje ali v organizaciji potrebujejo zunanjega svetovalca za izvedbo organizacijskih sprememb na področju menedžmenta lahko odgovorimo pritrdilno, vendar za določena področja kot so: strateško upravljanje, informacijske tehnologije, finančno upravljanje, trženje in distribucija in e-poslovanje. Za druga področja kot so: upravljanja človeških virov, upravljanje znanja, upravljanje produktivnosti in uspešnosti ter upravljanje celotne kakovosti je bolj smiselno izgraditi lastnega strokovnjaka ki bo bolje poskrbel za 
implementacijo določenih znanj v organizacijo, že zaradi svoje povezanosti z organizacijo in pripadnosti.

\section{Zaključek}

Analizirali smo znanstvene članke in druge publikacije iz področja menedžerskega svetovanja, s poudarkom na vlogi svetovalcev in najbolj pogostih pohval ozirom kritik svetovanja. Iskali smo odgovor na naše raziskovalno vprašanje, ali organizacija potrebuje zunanje svetovalce na področju menedžmenta za izvedbo organizacijskih sprememb. Velika večina avtorjev (Alvesson, M., 1993, Soriano, D. R., 2004, Schein, E. H., 1978, Mosonyi, S., Empson, L. and Gond, JP., 2020) opisuje na podoben način, kakšna je vloga svetovalca in na kakšen način naj bi se pristopilo svetovanju organizacijam. Tukaj ni velikih odstopanj.

Svetovalec je oseba, ki se zna prilagajati situacijam, ima bogate praktične izkušnje iz menedžmenta organizacij, zna predajati znanje in veščine drugim, zna razreševati zapletene menedžerske naloge, obvlada različne vloge; je strokovnjak, prerok, partner, poslovnež in uslužbenec (Kitay \& Wright, 2004), ima objektiven in neodvisen pristop, je fleksibilen in se zna osredotočiti na organizacijo kot celoto (Singleton, 2012). Vsi avtorji si niso enotni glede izbire svetovalca; ali izbrati zunanjega (Singleton, 2012) ali notranjega (Williams \& Woodward, 1994). Tako avtorji (Singleton, 2012, Williams \& Woodward, 1994, Mosonyi, Empson \& Gond, 2020, Menon \& Pfeffer, 2003) omenjajo, katere so prednosti in pomanjkljivosti enega in drugega pristopa. Rdeča nit je, da je notranji svetovalec, neobjektiven in ujet $\mathrm{v}$ notranja razmerja $\mathrm{v}$ organizaciji, nima potrebne širine in avtoritete.

Prispevek ugotovitev iz članka k managerski znanosti in stroki je teoretičen z možnostjo praktičnih implikacij. V teoretičnem delu smo na enem mestu povzeli vodilne svetovne avtorje na področju svetovalnega menedžmenta in opisali vlogo svetovalcev ter naklonjenosti in kritikam na njihov račun. To je lahko pomembno izhodišče organizacijam pri odločanju o angažmaju zunanjega svetovalca.

Pri izvedbi raziskave smo se soočali s posameznimi predpostavkami in omejitvam. Zanimale so nas ugotovitve strokovnjakov na svetovni ravni na področju svetovanja, zato nismo navajali slovenskih avtorjev. Področij svetovanja smo se samo dotaknili in jih nismo globlje obravnavali, saj to ni bil namen našega članka. Članek temelji na analizi člankov iz akademskih baz Web of science, Elsevier, Jstor, Emerald, niso pa bile izvedene empirične raziskave.

V raziskavi smo se omejili na teoretični del. Vsebinsko bi bilo smiselno nadaljevati raziskavo v smeri analize naklonjenosti in kritik posameznih področij svetovanja. Verjetno bi se pokazalo, da razmerje naklonjenosti in kritik niha glede na področje svetovanja. Bazo analiziranih člankov bi lahko razširili in za primerjavo stanja med svetovnimi trendi in tistimi v Slovenji vključili tudi slovenske avtorje. 


\section{Reference}

1. Alvesson, M. (1993). Organizations As Rhetoric: Knowledge-Intensive Firms And The Struggle With Ambiguity. Journal of Management Studies, 30(6), 997-1015. doi:10.1111/j.1467-6486.1993.tb00476.x

2. Bloomfield, B. P., \& Danieli, A. (1995). The Role Of Management Consultants In The Development Of Information Technology: The Indissoluble Nature Of Socio-Political And Technical Skills. Journal of Management Studies, 32(1), 23-46. doi:10.1111/j.1467-6486.1995.tb00644.x

3. Brandi, U., \& Elkjaer, B. (2019). Subtleties of knowledge sharing-Results from a case study within management consultancy. Knowledge and Process Management. 26(3) 185-196. doi:10.1002/kpm.1597

4. Bronnenmayer, M., Wirtz, B.W. and Göttel, V. (2016). Determinants of perceived success in management consulting: An empirical investigation from the consultant perspective. Management Research Review (3)6, 706-738. doi: 10.1108/MRR-06-20140145

5. Butler, N., \& Collins, D. (2016). The failure of consulting professionalism? A longitudinal analysis of the Institute of Management Consultants. Management \& Organizational History, 11(1), 48-65. doi:10.1080/17449359.2016.1151363

6. Canato, A., \& Giangreco, A. (2011). Gurus or Wizards? A Review of the Role of Management Consultants. European Management Review, 8(4), 231-244. doi:10.1111/j.1740-4762.2011.01021.x

7. Clark, T., \& Kipping M. (2012). The Oxford Handbook of Management Consulting. Oxford University Press: New York.

8. Clark, T., \& Salaman, G. (1998). Creating the "Right" Impression: Towards a Dramaturgy of Management Consultancy. The Service Industries Journal, 18(1), 18-38. doi:10.1080/02642069800000002

9. Craig, D. (2005). The scandalous inside story of the management consulting money machine. The Original Book Company, London.

10. Czarniawska, B. (2013). The Uncertainties of Consulting. International Studies of Management \& Organization, 43(3), 11-21. doi:10.2753/imo0020-8825430301

11. Czerniawska, F., \& May, P. (2004). Management Consulting in Practice. Kogan Page: London.

12. Dunford, R. (2000). Key challenges in the search for the effective management of knowledge in management consulting firms. Journal of Knowledge Management, (4) 4, 295-302. https://doi-org.nukweb.nuk.uni-lj.si/10.1108/13673270010379849

13. FEACO (2017), "Survey of the european management consultancy market 2016/17", Brussels, dostopno na: www.feaco.org/sites/default/files/sitepagefiles/Feaco\%20Survey.2016-2017.pdf

14. Fincham, R., \& Clark, T. (2002). Preface: Management Consultancy: Issues, Perspectives, and Agendas. International Studies of Management \& Organization, 32(4), 3-18.

15. Fincham, R. (2002) The Agent's Agent: Power, Knowledge, and Uncertainty in Management Consultancy. International Studies of Management \& Organization, 32(4), 67-86

16. Furusten, S. (2013). Commercialized professionalism on the field of management consulting. Journal of Organizational Change Management, 26(2), 265-285. doi:10.1108/09534811311328344

17. Grint, K., \& Case, P. (1998). The Violent Rhetoric of Re-engineering: Management Consultancy on the Offensive. Journal of Management Studies, 35(5), 557-577. doi:10.1111/1467-6486.00109

18. Jang, Y., \& Lee, J. (1998). Factors influencing the success of management consulting projects. International Journal of Project Management, 16(2), 67-72. doi:10.1016/s0263-7863(97)00005-7 
19. Kitay, J., \& Wright, C. (2004). Take the money and run? Organisational boundaries and consultants' roles. The Service Industries Journal, 24(3), 1-18. doi:10.1080/0264206042000247731

20. Kitay, J., \& Wright, C. (2007). From prophets to profits: The occupational rhetoric of management consultants. Human Relations, 60(11), 1613-1640. doi:10.1177/0018726707084302

21. Kubr, M. (2002), Management Consulting: A Guide to the Profession, International Labour Organization, Geneva.

22. Law, M. (2009). Managing consultants. Business Strategy Review, 20(1), 62-66. doi:10.1111/j.1467-8616.2009.00582.x

23. Leiby, J. (2018). The role of consultants and management prestige in management control system adoption. Accounting, Organizations and Society, 66, 1-13. doi:10.1016/j.aos.2018.03.003

24. McLachlin, R.D. (1999), Factors for consulting engagement success, Management Decision, (37)5, 394-404. https://doi.org/10.1108/00251749910274162

25. McKenna, C. (2006). The World's Newest Profession: Management Consulting in the Twentieth Century. Cambridge University Press, New York, NY.

26. Menon, T., \& Pfeffer, J. (2003). Valuing Internal vs. External Knowledge: Explaining the Preference for Outsiders. Management Science, 49(4), 497-513. doi:10.1287/mnsc.49.4.497.14422

27. Mosonyi, S., Empson, L. and Gond, JP. (2020). Management Consulting: Towards anIntegrative Framework of Knowledge,Identity, and Power. International Journal of Management Reviews, (22) 120-149. doi: 10.1111/ijmr.12218

28. Nees, D. B., \& Greiner, L. E. (1985). Seeing behind the look-alike management consultants. Organizational Dynamics, 13(3), 68-79. doi:10.1016/00902616(85)90031-2

29. Phelan, K. (2013). I am Sorry, I Broke Your Company. San Francisco: Berrett-Koehler Publishers, Inc.

30. Pinault, L. (2000). Consulting Demons: Inside the Unscrupulous World of Global Corporate Consulting, New York: Harper Business.

31. Schein, E. H. (1978). The Role of the Consultant: Content Expert or Process Facilitator? The Personnel and Guidance Journal, 56(6), 339-343. doi:10.1002/j.21644918.1978.tb04644.x

32. Singleton, A. (2012). How to Choose an Agency or Consultant. The PR Masterclass, 160-172. doi:10.1002/9781118756225.ch9

33. Soriano, D. R. (2004). External consultants in organisations: evaluating the Spanish case. The Service Industries Journal, 24(2), 34-50. doi:10.1080/02642060412331301242

34. Sturdy, A. (1997). The Consultancy Process - An Insecure Business? Journal of Management Studies, 34(3), 389-413. doi:10.1111/1467-6486.00056

35. Tavoletti, E., Cerruti, C., \& Grieco, C. (2019). Management consulting: a review of fifty years of scholarly research. Management Research Review. doi:10.1108/mrr-032018-0100

36. Van Nistelrooij, A., De Caluwé, L., \& Schouten, N. (2007). Management Consultants' Colourful Ways of Looking at Change: An Explorative Study under Dutch Management Consultants. Journal of Change Management, 7(3-4), 243-254. doi:10.1080/14697010701689950

37. Werr, A., Stjernberg, T., \& Docherty, P. (1997). The functions of methods of change in management consulting. Journal of Organizational Change Management, 10(4), 288307. doi:10.1108/09534819710175839

38. Wickham, L., \& Wilcock, J. (2016). Management consulting : delivering an effective project. Pearson: New York.

39. Williams A.P.O., Woodward S. (1994). Consultancy Roles. In: The Competitive Consultant. Palgrave Macmillan, London. https://doi.org/10.1007/978-1-349-13384-0_3 
40. Whittle, A. (2006). The paradoxical repertoires of management consultancy. Journal of Organizational Change Management, 19(4), 424-436. doi:10.1108/09534810610676635

$$
* * *
$$

Idriz Selimović je magistriral na Fakulteti za organizacijske študije v Novem mestu leta 2019. Dela v gospodarstvu in je opravlja različne funkcije, od vodje osnovne enote do tehničnega direktorja. Trenutno dela kot pomočnik direktorja proizvodnje, glavna naloga pa je uvajanje načel vitke organizacije v podjetje.

Mirko Markič je doktoriral na Fakulteti za organizacijske vede Univerze v Mariboru s področja organizacijskih ved na temo inoviranja. Po dvanajstih letih delovanja v gospodarstvu se je zaposlil na Fakulteti za management Univerze na Primorskem. Je redni profesor za področje menedžmenta in znanstveni svetnik ter vodja ali član 17 raziskovalnih projektov in projektov z gospodarstvom. Njegova bibliografija obsega več kot 600 enot s področja upravnih in organizacijskih ved ter javnega zdravstva (varstvo pri delu).

\section{Abstract: The Role of an External Consultant in Introducing Organizational Change}

Research Question (RQ): Does the company need an external consultant to make organizational changes?

Purpose: We want to examine the role of external consultants in introducing organizational change in an organization.

Method: In our article, we will use: systematic review guidelines, integrative study review guidelines, meta-analysis guidelines, and literature review scope guidelines. We selected the literature through the main academic bibliographic databases Web of science, Elsevier, Jstor, Emerald. We used the following keywords to search for relevant literature: Organizational Change, Consultant, Management, Introduction of changes, Process, Consultancy industry.

Results: While the added value that consultants can add to a company has long attracted the attention of management, critical interest in the consulting process is relatively new. However, the growing interest in consultants has also brought about a growing critical debate on the justification for hiring consultants. In our article, we will present the pros and cons of hiring external consultants.

Organization: The organization always needs sober thinking or needs an external consultant when introducing changes.

Society: Progress and success in the organization can be achieved without expensive external experts and always new approaches, simply by using "common sense". With this approach, we achieve that as many organizations as possible are dedicated to the implementation of this common sense in their processes.

Originality: The article highlights the key elements that need to be considered when introducing organizational changes in order to avoid costly external consultants.

Limitations / further research: The basis of the article is the theoretical findings of world authors from the studied field, the results of empirical research would be interesting.

Keywords: organizational change, consultant, management, introduction of changes, process, consultancy industry.

Copyright (c) Idriz SELIMOVIĆ, Mirko MARKIČ

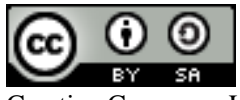

Creative Commons License

This work is licensed under a Creative Commons Attribution-ShareAlike 4.0 International License. 